\title{
Pleistocene glaciations of the northern Alpine Foreland
}

\author{
Markus Fiebig, Wien, Frank Preusser, Bern
}

\section{Introduction}

The Alps are an area on the globe where it was first recognised that climate and environment are not stable over geological time. The «ice age» theory and later a widely accepted Quaternary stratigraphy were developed in this region. Hence, palaeoclimate and -environmental research are long established in the Alpine region. The Alps are also important with regard to atmospheric circulation, representing the major weather divide in Europe. The area lies downwind of the North Atlantic Oscillation that strongly influenced climate change in the past.

The article begins with a brief overview of the historic aspects of the recognition of Pleistocene glaciations of the northern Alpine Foreland. The principles of the still commonly used stratigraphic system of Quaternary glaciations by PENCK \& BRÜCKNER (1901/09) are then presented and critically discussed in the light of basic assumptions and new evidence. Finally, some new ideas for a revised stratigraphic model for the Alps are presented.

\section{A brief history of the ice age theory}

The theory that Alpine glaciers are not stationary but highly dynamic bodies of ice was first recorded during the $17^{\text {th }}$ century, with the massive advance of glaciers such as that at Grindelwald. WAGNER (1680) wrote:

«These snow masses show such growth over the last few centuries that they force back the areas close with all the trees, the charming meadows and the neighbouring huts, and force the residents to relocate their houses elsewhere», (unpaged)

expressing the drama of changing environment at that time. The theory that glaciers once almost completely covered the Alps was first developed by VeNETZ (1833) and later promoted by Agassiz (1837) in particular. The main evidence for past glacier advances beyond the border of the Alps is based on the presence of erratic boulders in the Jura Mountains, for example, and the occurrence of moraine ridges in the lowlands. Although this theory was originally considered controversial, further evidence described by LouIs AGAssiz in areas such as the Scottish Highlands and New England finally convinced leading scientists of the time of the so called ice age.

\section{Classical Alpine Quaternary stratigraphy}

Following several decades of work in the Alps, PencK (1882) and PencK \& BRÜCKNER (1901/09) recorded an increasing amount of evidence for more than one glaciation. These authors observed a geomorphological phenomenon which is referred to as a "Glaciale Serie» (glacial series). This feature, frequently found in the Alpine Foreland, consists of three major elements: «Zungenbecken» (glacial [tongue] basin), «Endmoränenwall» (terminal moraine) and «Schotterfeld» (outwash plain) (Fig. 1). This geomorphological complex is interpreted as a record of the former maximum position of a stationary glacier. Of particular importance for Quaternary stratigraphy in the PENCK \& BRÜCKNER scheme are the outwash plains that extend from the maximum glacier position far into the foreland and so into areas that were not directly affected by Quaternary glaciations. Their position allows for the better preservation of older deposits in comparison to those areas closer to the Alps that have been subjected to erosion by repeated glacial activity. In the area of the Iller valley in Bavaria (Germany), for example, four stacked terrace levels can be observed (Fig. 2) Following the assumption that each terrace level represents an outwash plain, this suggests that the foreland has been glaciated (at least) four times. PENCK \& BRÜCKNER (1901/09) named these glaciations after rivers in the Northern Alpine Foreland, namely Günz, Mindel, Riss and Würm (from old to young). PenCK \& BRÜCKNER also demonstrated that four generations of glacial series exist. Based on evidence from outwash plains alone, the glaciations of Donau (EBERL 1930) and Biber (SCHAEFER 1957) were later introduced Looking at the morphological position of individual terraces in more detail reveals that most major terrace levels can be further subdivided. For example, five sublevels have been distinguished within the Biber complex, with the suggestion that these may reflect individual cold stages (BeCKer-Haumann 2001).

Still controversial is the chronostratigraphic position of the classical glaciations. Based on faunal remains and palaeomagnetic analyses of cover sediments on top of deposits attributed to the Donau glaciation, it is assumed that these deposits are older than the Olduvai chron and would hence be of Lower Pleistocene age considering that the Plio-/Pleistocene boundary is at 2600000 years (cf. HABBe et al. 2007; STRATTNER \& Rolf 1995). Chronological constraints of the younger glaciations remained tentative for nearly a century and have mainly been based on the assumption that ice expansion is directly driven by solar activity and 


\section{terminal moraine or} moranic belt

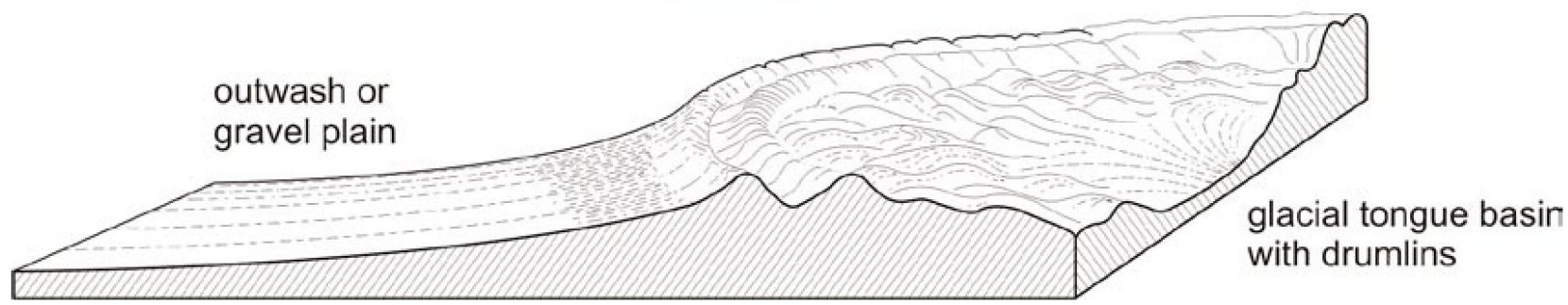

Fig. 1:The relationship between glacial basins, terminal moraines and outwash plains in former glacial landscapes was recognized by PENCK \& BRÜCKNER (1901/09). The authors argued that this so called «Glaciale Serie» (glacial series) was typical of mid-latitude glaciers (which are characteristically warm based).

Die Verknüpfung von glazialen Becken, Endmöranenwällen und Schotterfeldern in der ehemals glazialen Landschaft wurde von PENCK \& BRÜCKNER (1901/09) festgestellt. Diese Autoren folgerten, dass Gletscher der mittleren Breiten (die typischerweise eine warme Basis besitzen) die so genannte «Glaciale Serie» hinterlassen.

L'association étroite de bassins glaciaires, de moraines terminales et de plaines fluvioglaciaires dans des paysages précédemment englacés a été mise en évidence par PENCK \& BRÜCKNER (1901/09). Ces auteurs ont conclu que les glaciers des latitudes moyennes (qui sont typiquement des glaciers tempérés) laissent derrière eux ces séries glaciaires.

Graphics: after Penck \& Brückner (1901/09), redrawn by H. Pfalz-Schwingenschlögl

so-called Milankovitch forcing. One of the first of these chronostratigraphies was presented by KöPPEN \& WEGENER (1924), who gave ages of 592 000-543 000 years for Günz, 478 000-429 000 years for Mindel and 236 000-183 000 years for Riss. Present chronostratigraphies generally follow this scheme, although some important departures exist (cf. ELLWANGER et al. 1995; JERZ 1995; VAN HusEn 2004). These are based on the different assumptions made by different authors. For example, VAN Husen (2004) follows the concept of RAYMo (1997) and correlates major peaks in oxygen isotope records from the deep ocean (as a measure of global ice volume) with morphological evidence from the Alpine Foreland. According to this theory, the age of Günz would be ca. 650000 years, Mindel ca. 450000 years, Riss ca. 150000 years and Würm ca. 20000 years. However, this approach appears to have two major flaws: 1) it very much depends on which particular oxygen isotope record is being used as not all show maximum peaks of glaciations at times and 2) this approach a priori assumes that the dynamics of Alpine glaciation is synchronous with global ice volume. The latter appears to be a crucial point as it suggests that the Alpine chronology is not independent. Furthermore, there is evidence for pronounced regional differences in glacial dynamics from other regions on the planet (e.g. Preusser el al. 2005a; Svendsen et al. 2004).

Much better developed is the knowledge of the environmental evolution of the Alps during the Last Glacial Cycle (Würmian), between ca. 115000 years and
11500 years. A detailed review is provided by Preusser (2004) and the following gives only a brief summary of this paper. The Last Glacial Cycle, following the Last (Riss/Würm) Interglacial, is subdivided into three periods called Lower, Middle and Upper Würmian (Chaline \& JERZ 1984). The first comprises two phases of boreal (taiga-like) forest preceded, and followed by, open tundra vegetation. The Middle Würmian started with a pronounced cold phase and is further characterised by changes from cool to moderate conditions and culminated in a pronounced cold phase during the Upper Würmian when glaciers advanced to their last maximum position. The latter is well dated by radiocarbon, cosmogenic nuclides and optically stimulated luminescence to between 30 000-20000 years ago (IvYOchs et al. 2004; Preusser et al. 2007).

\section{Some reservations and new insights into Alpine Quaternary stratigraphy}

The classical Alpine Quaternary stratigraphy is mainly based on the assumption that the gravel deposits found in the Alpine Foreland represent melt-water sediments of outwash plains that were formed through glacial erosion, transport and termination of glaciers in the lowlands (cf. HABBE et al. 2007). As a consequence, almost any gravel deposit in the lowlands has been interpreted to represent a major glaciation of the Alps. The complex interplay between tectonic fragmentation, uplift and erosion of the Alpine body as well as climate change during the Pleistocene was, however, 


\section{oberer Deckenschotter}

\section{unterer Deckenschotter}

\section{Hochterrasse}
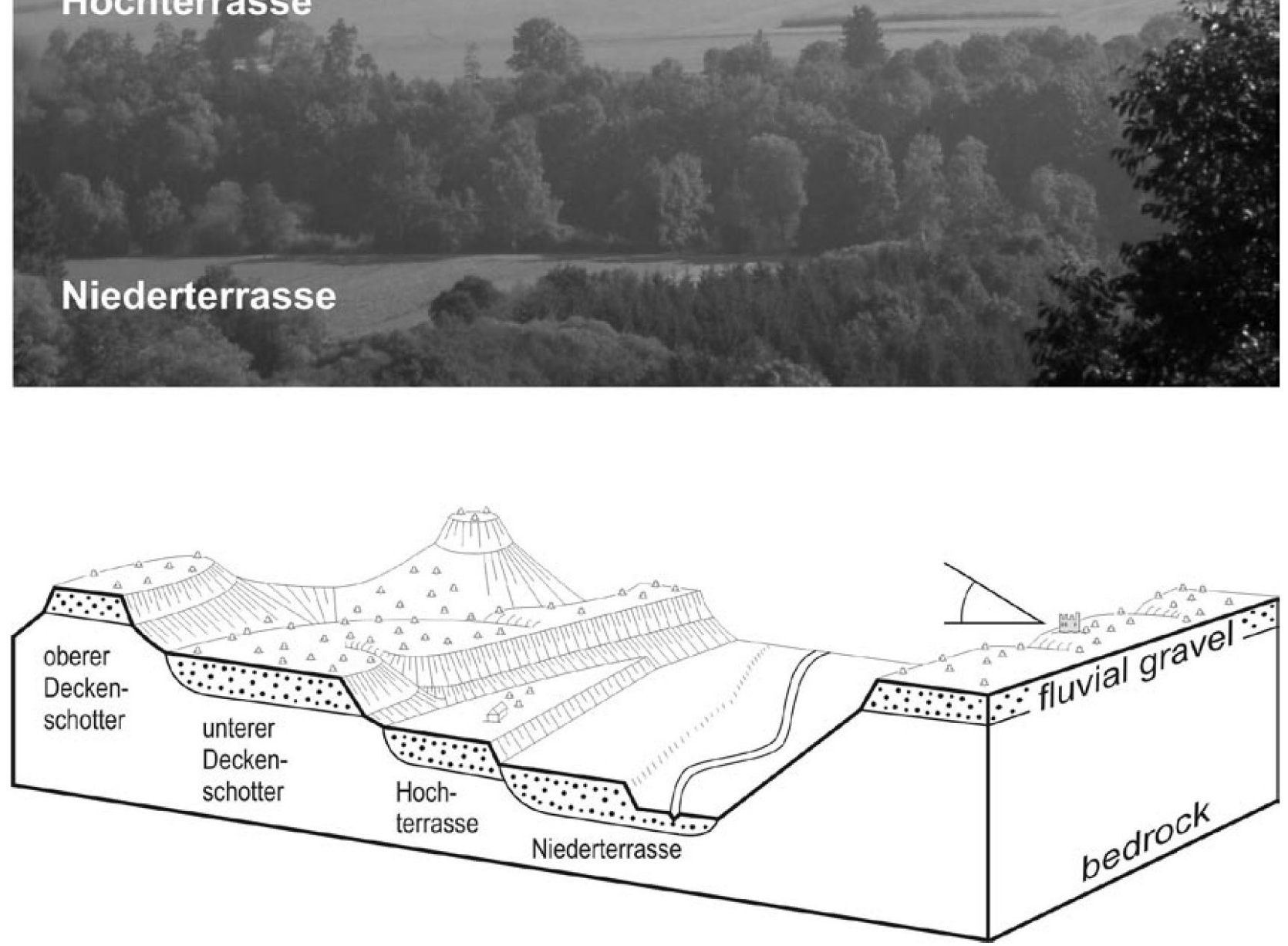

Fig. 2: View of four stacked terraces in the Iller Valley, as seen from Castle Marstetten (Bavaria, Germany) These terraces were interpreted by PeNcK (1899) as typical melt water deposits from four individual Alpine glacial events. Originally, the names of the terraces, as shown in the block diagram (redrawn after ScHolz \& ScHolz 1981) were used by PENCK (1889) only as mapping terms: all large terrace surfaces on valley bottoms were termed «Niederterrassen»; the large terraces on the valley slopes were referred to as «Hochterrassen» and gravels not directly connected to single valleys were referred to as the «Unterer» and «Oberer Deckenschotter». After 1899, PENCK hypothesized that the four individual gravel spreads he observed in the Iller valley were evidence for four glacial episodes (Würm, Riss, Mindel, Günz) across the whole Alpine area. Das Foto mit Blick von Burg Marstetten (Bayern) zeigt vier gestapelte Terrassen im Illertal.

La photographie montre quatre terrasses empilées dans la vallée de l'Iller, visibles depuis le château de Marstetten (Bavière, Allemagne).

Photo: M. Fiebig; Graphics: after Scholz \& Scholz (1981), redrawn by H. Pfalz-SchwingenschlögL 
investigated rather poorly, even though a clear fluvioglacial origin of gravel deposits is evidenced at a very few sites only. Beside this general concern about the origin of certain sediments the chronology of Alpine glaciations is also questioned. This is mainly due to the lack of independent age control which led several researchers to carry out tentative correlations with marine records of global ice volume. More recently, the application of new methods of numerical dating to sediments has resulted in debate over previous findings.

The oldest gravel units (Biber, Donau) are generally attributed to earliest Pleistocene times (setting its lower boundary at 2600000 years) (HABBE et al. 2007) and similar age constraints are, based on mammal remains, available for the «Deckenschotter» of northern Switzerland (Bolliger et al. 1996). Preliminary results of burial dating using cosmogenic nuclides imply a similar age (2 $300000+1000000 /-800000$ years) for fluvial sediments attributed to the «Günz gravel unit», although it should be noted that this dating approach is in a very early stage of development and is associated with large uncertainties. The subsequent younger unit, «Mindel», was found by burial dating using cosmogenic nuclides to be only $600000+/-200000$ years (Häuselmann et al. 2007). This Middle Pleistocene age is in agreement with the amount of local tectonic displacement but it is still controversial from the methodological point of view. The Meikirch drilling site in the Aare Valley, Switzerland, is a locality where Middle Pleistocene deposits have been dated by luminescence techniques and the Meikirch complex has recently been correlated with Marine Isotope Stage (MIS) 7 (Preusser et al. 2005b). An important issue raised is that the Meikirch complex consists of three well-developed warm phases (of interglacial character), and this casts doubt on the often applied assumption that interglacials occurred at 100000 years-cyclicity in the past. Loess deposits of similar age (MIS 7) and recording a similar pattern seem to cover «Günz gravels» in Upper Austria (Wels site) (Preusser \& Fiebig 2008). However, MIS 7 deposits have only recently been identified in the Alpine area and there may be many more sites with deposits of similar age.

The Penultimate Glacial Maximum (classically attributed to the «Riss gravel unit») represents in most regions the most extensive glaciation of the Quaternary. Surface exposure dating of erratic boulders attributed to this glaciation in the Jura Mountains suggests an age of ca. 150000 years (MIS 6) (Graf et al. 2007). However, luminescence dating of gravel deposits attributed to the Rissian identified two phases of aggradation between 60000 to 90000 years and 140000 to 170000 years (FIEBIG \& Preusser 2003). The first cluster of ages implies deposition during the early part of the Last Glacial Cycle and not prior to the Last Interglacial.

Finally, while it is generally accepted that the last glaciation of the Alps took place between 30000 and 20000 years ago, discussion is ongoing regarding further possible glaciations during the Last Glacial Cycle. Some preliminary evidence suggests that earlier glaciations followed by an almost complete meltdown of ice, occurred during MIS 5d (ca. 105000 years) and MIS 4 (ca. 65000 years) (Link \& Preusser 2006; Preusser 2004; Preusser et al. 2003, 2007).

\section{References}

Agassiz, L. (1837): Discours prononcé à l'ouverture des séances de la Société Helvétique des Sciences Naturelles. - In: Actes de la Société Helvétique des Sciences Naturelles 22, Neuchâtel: 5-32.

BeCKeR-Haumann, R. (2001): The depositional history of the Bavarian Allgäu area at the turn of the Tertiary/ Quaternary, Northern Alpine Foreland, Germany - a set of paleogeological maps. - In: Quaternary International 79: 55-64.

Bolliger, T., Fejfar, O., Graf, H.R. \& D.W. Kälin (1996): Vorläufige Mitteilung über Funde von pliozänen Kleinsäugern aus den Höheren Deckenschottern des Irchels (Kt. Zürich). - In: Eclogae geologicae Helvetiae 89: 1043-1048.

Chaline, J. \& H. JeRz (1984): Arbeitsergebnisse der Subkomission für Europäische Quartärstratigraphie: Stratotypen des Würm-Glazials (Bericht SEQS 5). - In: Eiszeitalter und Gegenwart 34: 185-206.

EBERL, B. (1930): Die Eiszeitenfolge im nördlichen Alpenvorland. - Augsburg: Benno Filser Verlag.

Ellwanger, D., Bibus, E., Bludau, W., Kösel, M. \& J. Merkt (1995): Baden-Württemberg. - In: BeNDA, L. (ed.): Das Quartär von Deutschland. - Berlin, Stuttgart: Gebrüder Borntraeger: 255-295.

Ellwanger, D., Von Koenigswald, W. \& O. Fejfar (1994): Die biostratigraphische Aussage der Arvicolidenfauna vom Uhlenberg bei Dinkelscherben und ihre morpho- und lithostratigraphischen Konsequenzen. - = Münchener geowissenschaftliche Abhandlungen A26, München: 173-191.

Fiebig, M. \& F. Preusser (2003): Das Alter fluvialer Ablagerungen aus der Region Ingolstadt (Bayern) und ihre Bedeutung für die Eiszeitenchronologie des Alpenvorlandes. - In: Zeitschrift für Geomorphologie, Neue Folge 47: 449-467.

Graf, A. A., Strasky, S., Ivy-Ochs, S., Akcar, N., Kubik, P.W., Burhkard, M. \& C. Schlüchter (2007): First results of cosmogenic dated pre-Last Glaciation Erratics from the Montoz area, Jura Mountains, Switzerland. - In: Quaternary International 164-165: 43-52.

Habbe, K.A., Ellwanger, D. \& R. Becker-HaumanN (2007): Stratigraphische Begriffe für das Quartär des 
süddeutschen Alpenvorlandes. - In: Quaternary Science Journal (Eiszeitalter und Gegenwart) 56:66-83. Häuselmann, P., Fiebig, M., Kubik, P.W. \& H. Adrian (2007): A first attempt to date the original «Deckenschotter» of Penck and Brückner in Bavaria. - In: Quaternary International 164/165:33-42.

Ivy-Ochs, S., Schäfer, J., KubiK, P.W., Synal, H.-A. \& C. SCHLÜCHTER (2004): Timing of deglaciation on the northern alpine foreland (Switzerland). - In: Eclogae geologicae Helvetiae 97: 47-55.

Jerz, H. (1995): Bayern. - In: Benda, L. (ed.): Das Quartär von Deutschland. - Berlin, Stuttgart: Gebrüder Borntraeger: 296-326.

Köpren, W. \& A. Wegener (1924): Die Klimate der geologischen Vorzeit. - Berlin: Gebrüder Borntraeger.

Link, A. \& F. Preusser (2006): Hinweise auf eine Vergletscherung des Kemptener Beckens während des Mittelwürms. - In: Eiszeitalter \& Gegenwart 55: 65 88

Penck, A. (1882): Die Vergletscherung der deutschen Alpen. - Leipzig: Tauchnitz.

Penck, A. (1889): Kartierung der quartären Einheiten auf Blatt Ingolstadt. - In: GüMBEL, V.C.W. (ed.): Geognostische Karte des Königreichs Bayern. Blatt Ingolstadt No. XV. Maass-Stab der Karte 1:100 000, Cassel.

Penck, A. (1899): Die vierte Eiszeit im Bereich der Alpen. - In: Vorträge zur Verbreitung naturwissenschaftlicher Kenntnisse 39, 3, Wien: 1-20.

Penck, A. \& E. Brückner (1901/09): Die Alpen im Eiszeitalter. - Leipzig: Tauchnitz.

Preusser, F. (2004): Towards a chronology of the Late Pleistocene in the northern Alpine Foreland. - In: Boreas 33: 195-210.

Preusser, F., Geyh, M.A. \& C. Schlüchter (2003): Timing of Late Pleistocene climate change in lowland Switzerland. - In: Quaternary Science Reviews 22: $1435-1445$

Preusser F., Andersen, B.G., Denton, G.H. \& C. SCHLÜChTER (2005a): Luminescence chronology of Late Pleistocene glacial deposits in North Westland, New Zealand. - In: Quaternary Science Reviews 24: 2207-2227.

Preusser, F., Drescher-Schneider, R., Fiebig, M \& C. SCHLÜCHTER (2005b): Re-interpretation of the Meikirch pollen record, Swiss Alpine Foreland, and implications for Middle Pleistocene chronostratigraphy. - In: Journal of Quaternary Science 20: 607-620.

Preusser, F., Blei, A., Graf, H.R. \& C. Schlüchter (2007): Luminescence dating of Würmian (Weichselian) proglacial sediments from Switzerland: Methodological aspects and stratigraphical conclusions. - In: Boreas 36: 130-142.

Preusser, F. \& M. Fiebig (2008): European Middle Pleistocene loess chronostratigraphy: Some considerations based on evidence from the Wels site, Austria.
- In: Quaternary International, published online: doi: 10.1016/j.quaint.2008.07.006.

RAYMO, M.E. (1997): The timing of major climatic terminations. - In: Paleooce anography 12: 577-585.

SCHAEFER, I. (1957): Erläuterungen zur Geologischen Karte von Augsburg und Umgebung 1: 50,000. - Bayerisches Geologisches Landesamt München.

Scholz, H. \& U. Scholz (1981): Das Werden der Allgäuer Landschaft. - Kempten: Verlag für Heimatpflege. StrattNer, M. \& C. Rolf (1995): Magnetostratigraphische Untersuchungen an pleistozänen DeckschichtProfilen im bayerischen Alpenvorland. - In: Geologica Bavarica 99: 55-101.

Svendsen, J.I., Alexanderson, H., Astakhov, V.J., Demdov, I., Dowdeswell, J.A., Funder, S., Gataullin, V., Henriksen, M., Huort, C., Houmark-Nielsen, M., HubBERTEN, H.W., INGÓlfsson, O., JAKOBSSON, M., KJÆR, K.H., Larsen, E., Lokrantz, H., LunkKa, J.P., Lys̊̊, A., Mangerud, J., MatiouchKov, A., Murray, A.S., Möller, P., Niessen, F., Nikolskaya, O., Polyak, L., SaArnisto, M., Siegert, C., Siegert, M.J., Spielhagen, R.F. \& R STEIN (2004): Late Quaternary ice sheet history of northern Eurasia. - In: Quaternary Science Reviews 23 1229-1271.

VENETZ, I. (1833): Mémoire sur les variations de la température dans les Alps de la Suisse. - In:Denkschriften der Allgemeinen Schweizerischen Gesellschaft für die Gesamte Natur 1,Zürich:1-38.

VAN Husen, D. (2004): Quaternary glaciations in Austria. - In: EHLERs, J. \& P.L. GIBBARD (eds): Quaternary glaciations - extent and chronology. Part I: Europe. - In: Developments in Quaternary Science 2, Amsterdam: 1-13.

WAGNER, J.J. (1680): Historia naturalis Helvetiae coriosa. - Zürich: Johann Heinrich Lindinner.

\section{Abstract: Pleistocene glaciations of the northern Alpine Foreland}

It is now well known that climate and environment are not stable over geological time and Alpine Quaternary stratigraphy has widely evolved since the first discussions on Pleistocene glaciations nearly two centuries ago. Originally, in the late $19^{\text {th }}$ century, three and later four glacial periods were postulated but with more research it appears that several more cold phases and separate ice advances occurred. To solve the history of climate and environmental change, a reliable time frame for the available geomorphological evidence is necessary. While some very interesting results have been presented in recent years, the amount of numerical dating is still very small and needs to be improved in order to unravel the full story of the Alpine palaeoclimate.

Keywords: Alps, glaciation, Pleistocene, climate change, dating 


\section{Zusammenfassung: Pleistozäne Vergletscherungen des nördlichen Alpenvorlandes}

Es ist bekannt, dass sich Lebensraum und Klima im Laufe geologischer Zeiträume sehr stark verändern, und die alpine Quartärstratigraphie hat sich seit der Erkenntnis, dass es pleistozäne Vergletscherungen der Alpen gab, stark weiterentwickelt. Ursprünglich, im späten 19. Jahrhundert, wurden drei und später vier Vergletscherungen angenommen, doch nach dem heutigen Forschungsstand scheinen bedeutend mehr Kaltphasen und Eisvorstösse wahrscheinlich. Um die Geschichte der Klima- und Umweltveränderungen klären zu können, braucht es einen verlässlichen Zeitrahmen für die vorhandenen geomorphologischen Hinweise. Einige sehr interessante Ergebnisse konnten in den letzten Jahren vorgelegt werden, doch die Anzahl an numerischen Datierungen ist immer noch relativ gering und muss deutlich erhöht werden, um die komplette Geschichte des alpinen Paläoklimas enträtseln zu können.

Schlüsselwörter: Alpen, Vergletscherung, Pleistozän, Klimawandel, Datierungen

\section{Résumé: Glaciations pléistocènes du versant nord des Alpes}

Il est aujourd'hui bien établi que le climat et l'environnement ne sont pas stables sur des périodes géologiques. De même, l'étude de la stratigraphie alpine quaternaire a fortement évolué depuis les premiers relevés des glaciations pléistocènes effectués il y a deux siècles. A la fin du XIX ${ }^{\text {me }}$ siècle, il était admis que trois - plus tard quatre - périodes glaciaires avaient eu lieu, alors qu'aujourd'hui, un plus grand nombre de phases froides est admis. Pour clarifier l'histoire climatique et environnementale, un cadre temporel permettant d'analyser les faits géomorphologiques existants est nécessaire. Bien que quelques résultats très encourageants aient été présentés durant ces dernières années, la somme de données numériques reste toujours faible et nécessite d'être complétée, de manière à déchiffrer l'histoire complète du climat des Alpes du Pléistocène.

Mots-clés: Alpes, glaciation, Pléistocène, changement climatique, datation

Prof. Dr. Markus Fiebig, Department für Bautechnik und Naturgefahren, Institut für Angewandte Geologie, Universität für Bodenkultur Wien, Peter JordanStraße 70,A-1190 Wien, Austria.

e-mail: markus.fiebig@boku.ac.at

PD Dr. Frank Preusser, Institut für Geologie, Universität Bern, Baltzerstrasse 1+3, CH-3012 Bern, Switzerland.

e-mail: preusser@geo.unibe.ch

Manuskripteingang/received/manuscrit entré le 8.5.2008

Annahme zum Druck/accepted for publication/accepté pour l'impression: 15.9.2008 